\title{
The Professional Integration of Internationally Trained Accountants: Quebec Evidence
}

\author{
Michel Sayumwe, Christelle-Odile Happi \\ University of Quebec at Montreal, Montreal, Quebec, Canada \\ Email: sayumwe.michel@uqam.ca
}

How to cite this paper: Sayumwe, M., \& Happi, C.-O. (2021). The Professional Integration of Internationally Trained Accountants: Quebec Evidence. Modern Economy, 12, 91-106.

https://doi.org/10.4236/me.2021.121005

Received: May 5, 2020

Accepted: January 26, 2021

Published: January 29, 2021

Copyright (c) 2021 by author(s) and Scientific Research Publishing Inc. This work is licensed under the Creative Commons Attribution International License (CC BY 4.0).

http://creativecommons.org/licenses/by/4.0/ (c) (i) Open Access

\begin{abstract}
The purpose of our study is to understand the factors of barriers to the integration of internationally trained accountants into the accounting profession in Quebec. Using a qualitative methodology, our research is a multi-case study type based on semi-structured interviews with fourteen internationally trained accountants. Despite the increasing number of immigrants who decide to settle in Quebec, and the shortage of labor, many internationally trained professionals find it difficult to integrate into their professional field. With regard to the accounting profession, several studies have been conducted before but very few were looking to the Province of Quebec and the results obtained differ from one context to another. In addition, new barriers emerge with each study justifying the need for an exploratory approach to better understand the subject. Our theoretical framework is based on the work of Weber $(1971,1975)$ who focused on the theory of social closure. We find that the barrier factors to the integration of internationally trained accountants into the accounting profession are informational, discriminatory, procedural and related to technical skills. Other factors emerge such as family and social factors, age, the influence of people from the same ethnic community and the immigrant's state of mind.
\end{abstract}

\section{Keywords}

Professional Integration, Profession, Internationally Trained Professional, Barriers to Integration, Social Closure, Chartered Professional Accountant

\section{Introduction}

The profession on which regulation is exercised and the modalities of the latter vary from one context to another, mainly depending on the local history of each profession and the legal and regulatory traditions which surround it (Bédard et 
al., 2018). Regulated professions account for $10 \%$ of employment in Quebec. Out of the 50,000 immigrants that Québec receives each year, approximately 5000 apply to be admitted to one of the 46 professional orders. According to the Interprofessional Council of Quebec, the question of improving the career paths of immigrant professionals and ultimately facilitating their integration into regulated professions is important in Quebec.

In our case, we focus on the Quebec Order of Chartered Professional Accountants (CPA). To this end, the Ordre des CPA du Québec, like other Quebec professional orders, must exercise specific functions in terms of issuing permits to practice for candidates to the profession. With immigration, the Order must face great demographic challenges and do everything to adapt to them. For internationally trained professionals, there are steps to follow and these steps differ depending on whether the degrees were obtained outside of Canada or in countries with a reciprocal agreement. The Order has many recognition agreements with a number of countries, such as the United States, France, New Zealand and India, which accelerates the process. However, in 2017, the bulk of the requests came from Africa, a group of countries with which the Order has not concluded agreements. "We must therefore study these requests on a case-by-case basis, because we must ensure that the law, which governs the obtention of the designation, allows us to grant them their equivalence," said Ms. Geneviève Mottard, President and CEO of the Quebec CPA Order. Ms. Mottard states also that the integration of newcomers remains a challenge despite the fact that their background and training are not always adequate.

The literature on professionalization and more particularly on professional integration is vast (Annisette, 2017; Annisette \& Trivedi, 2013; Boudarbat \& Boulet, 2010; Carnegie \& Edwards, 2001; Jacobs, 2003; Poullaos, 2016; Roger \& Orthodoxia, 2011). The issue of barriers to professional integration has been addressed, but the results vary from one context to another. The theory of social closure developed by Weber (1971) has been widely discussed in the literature to understand all forms of social exclusion. For some authors like Collins (1979) and Parkin (1979), despite the evolution of society, the modes of social closure are more based on collectivist criteria (race, ethnicity). However, for other authors such as Murphy (1984) and Murphy (1988), society has evolved and individualistic criteria (education, citizenship, credentials) are more emphasized. In our work, we want to understand in the light of this theory the factors of barriers to the integration of internationally trained accountants into the Quebec CPA Order. In the following sections, we present our theoretical approach and we review the literature on the various factors addressed on the accounting profession.

\section{The Neo-Weberian Approach to Social Closure and Our Research Problem}

The theory of social closure was proposed by Weber (1971) with the aim of de- 
veloping a general framework for understanding all forms of exclusion within society. The German sociologist makes a difference between open and closed social relationships: a social relationship is "open" to the outside "when according to the regulations in force, anyone who is actually able to do so is allowed, and the wishes to participate in reciprocally oriented activity according to the significant content that constitutes it"; on the other hand, a social relationship is "closed" to the outside "as long as the extent that its significant content or its regulations in force exclude or limit participation, or link it to conditions" (Weber, 1975). The tendency towards social closure and the establishment of "closed relationships" is therefore quite great among the groups which manage to "appropriate" a chance, which manage to occupy a privileged position, which they obviously tend to conserve and defend it (Weber, 1975).

For Baluta (2011), the concept of "social closure" is supplemented by the concepts of social exclusion, monopoly of educational capital and also by the concepts of discrimination. This theoretical framework allows a complex questioning of the different levels of formulation and introduction of rules and exclusive practices. Social closure codes are therefore broadly defined as the formal and informal rules governing the practice of monopoly and exclusion on whatever basis, be it race, ethnicity, gender, religion, citizenship, property, education or others, such as professional license (Hammond et al., 2009).

Conventional wisdom and some interpreters of Weber (1971) argue that the historical development of capitalism has been accompanied by a gradual transition from modes of social closure based on collectivist criteria (such as family lineage, class, race, ethnicity and gender) and individualistic criteria (such as education and professional designations).

While Weber (1971) and some Neo-Weberians (eg. Parkin, 1979) consider education and property to be more or less equal determinants of social class and privilege, Murphy (1984) maintains that there are a hierarchy in the types of social closings. In most capitalist societies, property is the main form of closure, while credentials, including education and professional licenses, derive from or depend on the mode of closure. For example, property rights in capitalist companies give employers (such as large accounting firms) the right to specify professional qualification requirements, which is then used to impose additional exclusion rules. Murphy (1984) argues that closure based on credentials (including professional licenses) is, therefore, primarily derived from closure based on property. While derived forms of exclusion can have a legal basis, as in the case of apartheid laws, much of the social stratification in contemporary capitalist societies is according to Murphy (1988) based on "the differential historical accumulation of private property on the resulting monopolization of market opportunities through the formation of networks, alliances and the taxation of owners", on the linguistic and cultural assumptions concerning the competence for positions and the career. Our analysis is guided by the theoretical model of Murphy. 


\section{Aspects of Social Closure in the Accounting Profession}

The regulated profession of chartered accountant is a special case of the closed market with access control to the profession, reserved tasks and guarantees of technical competence (Paradeise, 2008). Following the interactionist sociologists of Chicago, numerous works, dealing with a great diversity of professional groups, have shown how these are built and recomposed in ceaseless struggles and negotiations, both at their borders and at their heart. The accounting professions, and in particular the accounting profession, illustrate this phenomenon in different national contexts (Dietrich \& Moysan-Louazel, 2012). According to Annisette (2003), the accounting profession depends on the clientele like many other professions (such as that of educator or doctor) and this dependence increases the probability that accounting firms recruit people sharing in a to some extent the same context and the same social characteristics. The similarity between ethnicity, educational background and class history, tastes, language and cultural skills found between chartered accountants and their clients testifies to the similarity of ethnic origins, educational background, class, tastes, linguistic and cultural skills (Hammond et al., 2009).

A vast literature focused on the imperial or colonial development of accounting as a means of controlling the resources of an empire from a distance in differents countries like England (Chua \& Poullaos 1998, 2002), United States (Dyball, Poullaos, \& Chua, 2007) or Portugual (Gomes, Carnegie, \& Rodrigues, 2013). In Australia, it was the development of capital markets that initiated the creation of associations, but some previous professional associations were not easily accepted because there was a fear that monopolies would be created, which was contrary to spirit of free competition (Chua \& Poullaos, 1998). Professional associations in Australia, the Canadian and South African colonies are largely inspired by the Anglo-American model and seek mutual recognition with the Institute of Chartered Accountants in England and Wales (ICAEW). Mutual recognition of Chartered Accountants (CA) brands can be seen as a form of postcolonial expansion (Chua \& Poullaos, 2002).

Annisette (2000) argues that it is the postcolonial state-building process that influences the important contours of the "third world" postcolonial accounting bodies that have emerged. The author shows how British professional organizations thwarted the Trinidadian government's attempt to master accountant training through the university.

Some scholars have focused on the the state-profession relationship. The role of the State was considered more decisive in the countries of continental Europe (Ramirez, 2001; Caramanis, 2002) than in the Anglo-Saxon countries (Willmott, 1986; Poullaos, 2009). The State is a heterogeneous actor whose different administrations can sometimes pursue divergent objectives. Using economic, social and political arguments, professional groups seek to obtain a delegation of public authority from the state in order to protect their area of practice (Walker, 1988; Uche, 2002; Gobe, 2011). 
On the other hand, Annisette (2017) maintains that the closure based on the protectionism of the letters of reference, was a particularly effective strategy in the projects of professionalization of accounting, by the statutes which were at the heart of the controversial clauses of Bill 158 aiming at the creation jobs in Ontario, Canada.

Some studies have focused solely on race, but defining race not as skin color like Hammond et al. (2009), but rather incorporating the physical condition factor. Annisette \& Prasard (2017), exploring the way in which the concept of race has been used in the literature, identify the contours of existing accounting research on race and discuss the pitfalls and challenges of research in this field.

In some contexts, racial discrimination is based on ethnicity, including characteristics such as country of origin and language. Guozhen et al. (2016) study racial discrimination when graduates of various ethnicities aspire to enter the accounting profession. His study illustrates the benefits of careful and detailed operationalization of ethnicity.

\section{Methodology}

In this section, we present the methodology that we use to answer our research question. It is qualitative in nature and based on multi-case studies. We present our sample which is made up of 14 professional accountants trained abroad. For the analysis of our data, we use NVIVO 12 software (footnote) for transcription, coding of extracts from our semi-structured interviews. Finally, we present our results.

Like the other qualitative research approaches, the case study is part of the daily context of the participants in order to be based on their perspective to better understand the case in depth by recognizing its complexity and context (Gall et al., 2007). According to Yin (2014), the case study is well suited to research aimed at discovering the "how" and the "why" of phenomena. This qualitative research is mainly based on the collection and analysis of data from 14 individual interviews with professional accountants who graduated outside Canada and the United States.

\subsection{Selection of Cases}

This study focuses on immigrant professional accountants who obtained their credentials outside Canada, the United States and France. The selection of cases was made in order to obtain a diversified sample. We have taken into account the country of origin, initial training, professional experience and different stages of the steps aimed at integrating the accounting profession in Quebec. The criteria for inclusion of our sample are as follows: the duration of residence in Quebec (minimum one year and maximum 20 years), to be a person born abroad, to be in the process that leads to the CPA designation or be already a $\mathrm{CPA}$, and to be under 65 .

Thus, 14 immigrant accounting professionals participated in the interviews. We stopped recruiting participants once data saturation was reached, following 
the completion of the 14 interviews.

Recruitment was made possible thanks to the collaboration of the Department of Accounting sciences of the School of Management at the University of Quebec in Montreal (ESG UQÀM). Former and current students from this Department were asked to participate in this study. Therefore, we recruited 10 participants, including 6 for the certificate, 3 for the CPA graduate program and for the research stage of the internship. We also went through a community organization called CACI (Centre d Aide aux Communautés Immigrantes) through which we were able to recruit three other participants. It is a non-profit organization working to facilitate the reception and integration of immigrants in general.

The interviews conducted from March 8 to 30, 2019, with each participant being met only once. All of the interviews began with an open-ended general question about the integration of immigrant accountants in Quebec. The rest of the interview aims to circumscribe the respondent's perception of the barriers to this integration. The various themes that were addressed in the interview are inspired by the synthesis of barriers and perceptions cited in the literature, most of which are not specific to immigrant accountants. These general themes are represented by linguistic, socio-cultural, informational, financial, procedural, discriminatory, and technical constraints. It is important to note that these themes are not exhaustive, and during the interviews, the open questions allowed us to grasp the specific difficulties experienced by immigrant accountants that have not been raised in the literature.

\subsection{Semi-Structured Interviews}

Using NVivo 12 software, we transcribed and coded our interviews. In the transcripts, we identified the text segments related to the research question, namely the barriers to the professional integration of professional immigrant accountants. We then encoded them in the different nodes. Our Knots correspond to the different factors mentioned in our interview guide. In our case, we have eight nodes corresponding to the different barrier factors raised in our interview guide. Nodes were added over time depending on what our participants told us in our interviews. From these knots emerged certain themes that we had not alluded to in our interview guide. This entire step was done with NVivo 12 software. Finally, we have a total of sixteen nodes.

The research project was previously submitted for approval to the research ethics certification committee of the University of Québec in Montréal. Prior to participating in the interviews, they were also provided with a consent information form for the interview and audio recording of the interview. All measures have been taken to respect the anonymity of the participants.

\section{Preliminary Analysis}

The first participant is of Rwandan origin. She is 50 years old, single, childless 
and has lived in Quebec for 15 years. Her professional experience in his country of origin is ten years. She obtained a master's degree in business administration in Quebec, and a bachelor's degree in accounting sciences. She is currently continuing her studies to obtain a graduate diploma specializing in accounting practice to join the Quebec CPA Order and is in the research phase of the internship.

The second participant is a 42-year-old Haitian accountant, married and father of 2 children. He has lived in Quebec for 7 years and has 8 years of experience in his country in Haiti. He has completed his university studies and is already a member of the Order of Chartered Professional Accountants. He currently works in an accounting firm.

The third participant is from Burundi. She arrived in Quebec 3 years ago and is currently at the end of her Certificate program in specialized accounting. She has 10 years of experience as an accountant in her home country. She is married and the mother of 5 children. She is 48 years old.

The fourth participant is from Cameroon. He is married and father of 2 children. Currently, he is almost at the end of his CPA graduate program. He arrived in Quebec 4 years ago and is 38 . He had 7 years of professional experience as an accountant in his home country.

The fifth participant is from Cameroon. He arrived in Quebec 3 years ago. He is married and has two children. He is enrolled in the CPA graduate program. He had 10 years of experience as a professional accountant before arriving in Quebec. He is 43 years old.

The sixth participant is from Morocco. He is 42 years old and worked as a professional accountant in his country of origin for 2 years. He arrived in Quebec 14 years ago. Currently, he works as a CPA in his own accounting firm. He is married and has three children.

The seventh participant is from Morocco, he arrived in Quebec 5 years ago. $\mathrm{He}$ is currently in the internship search stage. He is 35 years old and is single. He worked as an accountant for 3 years in his country of origin.

The eighth participant is from Ivory Coast. He arrived in Quebec 10 years ago. Currently, he is a CPA and works in an accounting firm. He is 32 years old and single. He had no professional experience in his country of origin.

The ninth participant is from Burkina Faso. He arrived in Quebec 3 years ago. Currently, he is a Certificate program student. He is 39 years old and has 10 years of experience as an accountant in his home country. He is married and has two children.

The tenth participant is from Haiti. He arrived in Canada 3 years ago. He is 42 years old, is married and has two children. Currently, he is at the end of his Certificate program. He practiced for 10 years in his country of origin.

The eleventh participant is from Cameroon. She is single and has one child. She arrived in Quebec 2 years ago. She is 34 years old. She worked for 6 years as an accountant in her country of origin. Currently, she is pursuing her Certificate program and, simultaneously, she works in an accounting firm. Right after ar- 
riving in Quebec, she completed a professional studies diploma in accounting.

The twelfth participant is from Cameroon, he has been in Quebec for a year. He has 14 years of professional experience as an accountant in his country of origin. He owned an accounting firm before arriving in Quebec. He obtained his accounting designation in France by taking distance courses just over a year ago. He is 42 years old, is married and has 5 children.

The thirteenth participant is 38 years old. She has been in Quebec for 1 year. She has 12 years of experience as an accountant in her home country. She was the manager of an accounting firm before arriving in Quebec. She also earned her designation in France by taking distance courses just over a year ago. She is married and the mother of 5 children.

The fourteenth participant is from Haiti and is 42 . He arrived in Quebec 3 years ago, is married and father of 5 children. He has 8 years of experience in his home country and currently studies in the Certificate program (Table 1).

\section{Results Analysis: Barriers to Integration}

Our results show that the barriers to professional integration perceived by immigrant accountants are informational, discriminatory, related to technical skills and, to a lesser extent, socio-cultural. Barriers to the integration of immigrant accountants are present at three levels: before and directly after arriving in Quebec, during the university courses, and finally when looking for the compulsory 24-month internship. From these results, we group these factors into two main

Table 1. Overall percentage attributable to each of the factors.

\begin{tabular}{|c|c|}
\hline Encoding & Percentage of the covering \\
\hline Nodes $\backslash \backslash T e c h n i c a l$ competencies & $20.11 \%$ \\
\hline Nodes $\backslash \backslash$ People with the same ethnic community & $15.35 \%$ \\
\hline Nodes $\backslash \backslash$ Procedural barriers & $10.38 \%$ \\
\hline Nodes $\backslash$ Social Network & $9.32 \%$ \\
\hline Nodes $\backslash$ Informational Factor & $7.40 \%$ \\
\hline Nodes $\backslash \backslash$ Discriminatory Factor: Cumulative average & $6.84 \%$ \\
\hline Nodes $\backslash$ Cultural Barriers & $4.60 \%$ \\
\hline Nodes $\backslash \backslash$ Economic size of the country of origin & $4.49 \%$ \\
\hline Nodes $\backslash$ The age of the immigrant person & $4.40 \%$ \\
\hline Nodes $\backslash$ The financial factor & $3.66 \%$ \\
\hline Nodes $\backslash \backslash$ The immigrant accountant accent & $3.49 \%$ \\
\hline Nodes\\
lack of Quebec professional experience & $2.68 \%$ \\
\hline Nodes $\backslash$ Linguistic barriers & $2.63 \%$ \\
\hline Nodes $\backslash$ Other discriminatory factors & $1.91 \%$ \\
\hline Nodes $\backslash$ immigrant state of mind & $1.42 \%$ \\
\hline \multirow[t]{2}{*}{ Nodes $\backslash I$ Immigrant personality } & $1.42 \%$ \\
\hline & $100.00 \%$ \\
\hline
\end{tabular}


groups: barrier factors under the immigrant's control and factors beyond the immigrant's control.

\subsection{Before and Directly after Arrival in Quebec}

At this stage, we have the information barrier factors, linked to people from the same ethnic or cultural community as the immigrant, the language barrier factors. At this stage we classify these factors in the category of those under the control of the immigrant with the exception of barriers related to family and social factors.

\subsubsection{Information Barriers}

Information barriers are particularly linked to the type of information that everyone receives upon their arrival in Quebec when they want to undertake procedures and also throughout their journey. Information barriers were reported by several participants. These barriers have been identified along the way of the various participants in the professional integration process. They can be grouped according to 3 phases: before arrival in Quebec, upon arrival in Quebec, and during the process of integration of the accounting profession. Three of our participants dwelled on the subject, saying that there would be a lack of information about the different stages to go through and especially the real difficulties they would face during their journey in the integration process.

The other participant who spoke on the subject reported a lack of information in general, but above all, in relation to a specific barrier: all the steps needed to be granted the CPA designation.

By analyzing these different verbatim and based on our results presented above, we find that the lack of information is considered by our respondents as a barrier in their integration process. The time they take to gather all the information they need and the quality of the information they receive will be decisive aspects for their further integration into the process. Respondents who raised the issue of information also spoke of barriers related to people of the same ethnic community because much of the information they receive upon arrival comes from these people.

\subsubsection{Barriers Related to People from the Same Ethnic or Cultural Community as the Immigrant}

Several participants spoke of the influence of people from the same ethnic community on their integration process. More particularly, this influence would come from advice and information gathered from people in the same community upon their arrival. Indeed, depending on the information received, some immigrants may decide either to continue in their profession or to make a career change.

"There is also the fact of meeting the wrong people to get the information. For example, other immigrants who did not succeed when they arrived and who are not well integrated. It is at this level that the immigrant's determination and 
self-confidence must play a big role" (Participant 1).

The quality of the information received from their peers can create discouragement and even see an abandonment or outright reorientation of the immigrant who would like to integrate the profession.

\subsubsection{The Financial Factor}

The financial factor did not appear to be a barrier factor for our participants for their integration. Through loans and grants provided by the State to help immigrants finance their studies, the immigrant accountant does not see the financial factor as a barrier. The only difficulty that was noted comes from our participant 1 .

Apart from these factors, it emerged, according to several of our participants, that factors such as the number of children and marital status are determinants and can be considered as barriers to integration into the profession. These factors make them part of those who are out of the immigrant's control.

\subsubsection{Barriers Linked to Family and Social Factors}

By family and social factors, we mean the number of dependent children of the immigrant and his marital status upon arrival. An immigrant who arrives in Quebec with his children or dependents, especially young ones, has no one to whom to refer to request a household help. The precarious financial situation they face upon arrival does not allow them to hire someone to help them. They are sometimes forced to postpone their studies until they can take care of their families.

Based on what emerged from the interviews, we also added the factor "state of mind of the person at the time of his arrival in Quebec". In this case, its integration will depend on several questions. Did the participant have clear goals for their career orientation upon arrival? Did he come to make money without making much effort? Does he want to make money while building a professional career? These questions come out of the interview with our thirteenth participant.

\subsubsection{During the University Course Leading to the CPA Designation}

It is at this stage that the barriers perceived by the participants are most numerous. The notion that came up often in many interviews was the lack of information regarding the grades that must be obtained during all university training in order to progress to the next level and also to hope to get a good internship and a good job. The barrier factors cited in this step fall into the category of factors beyond the immigrant's control.

\subsection{Procedural Barriers}

By procedural barriers, we mean all the steps to be followed by the immigrant accountant to complete his university courses and have his professional designation. During our interviews, some of our respondents stated that they were a little discouraged by all the steps to access the CPA designation that they consi- 
dered quite long.

After analyzing the verbatim, we note that all of the participants underline the complexity of the procedure leading to the CPA designation, in particular the length of the process and the different stages leading to it.

\subsubsection{The Size of the Economy of the Country of Origin}

According to the verbatim, the size of the economy of the country of origin is very important. The country of graduation can be considered as a barrier to the integration of certain professionals trained abroad in the sense that there are professionals who have obtained diplomas in the countries with which Quebec has reciprocity agreements. These are countries like France. Two of our respondents had their professional designation in a French school by taking distance courses. Upon their arrival in Quebec, they were just asked to follow 2 courses in the form of a seminar. They will not have to take additional exams before obtaining the professional designation.

\subsubsection{When Looking for the Internship}

When looking for the internship, several participants said they encountered several difficulties. These are barriers related to technical skills, social network and discriminatory factors. We would like to point out that, the CPA work in all sectors of economic life but, according to the information collected on the CPA du Québec site, to become a CPA auditor and to be authorized to sign audit reports, among others, as soon as the CPA permit is issued. The candidate must find a pre-approved training environment allowing them to acquire the necessary audit skills (including the minimum number of hours required for an audit mission). This requirement is fulfilled in accounting firms unlike the internship done in business.

\subsubsection{Barriers Related to Technical Skills}

This is the set of skills required for the immigrant to directly occupy an accounting position upon arrival in Quebec. These factors relate to the professional experience acquired by the immigrant before his arrival in Quebec and his previous academic course. During our interviews, some of our respondents perceived that they could be barriers to their integration the fact that he had no Quebec professional experience. In addition, some claimed that the accounting system was quite different from those with which they had worked in the past. The differences were noted in particular in terms of taxation and law.

With regard to the verbatim, we note that the non-recognition of prior learning acquired outside Quebec both professionally and academically can be considered as a barrier to integration. In the same order, the practical and theoretical content of the courses taken in the country of origin, the ability to use the computer tool, the mastery of the accounting software used in Quebec companies, can be a barrier for the immigrant in his path to integrate the profession. This means that during the search for an internship and when looking for a job, recruiters will give a better chance to someone who already has these skills. 


\subsubsection{Social Network Barriers}

Interviews with our respondents allowed us to understand that the absence of a social network could be considered as a barrier to the integration of foreign professionals into the profession. In fact, several of our respondents said they were faced with a lack of references when looking for an internship or looking for a job.

Through our verbatim, we note that the absence of a social network or a poorly developed social network in Quebec can be considered as being a barrier to the integration of foreign professionals within the profession in Quebec. However, we want to note that this factor is part of the category of those controllable by the immigrant insofar as it can build a social network by bringing together organizations that work for the integration of immigrants and by participating in different organized events.

\subsection{Barriers Related to Discriminatory Factors}

Through our interviews, we identified discriminatory factors experienced by some of our participants and which for them were obstacles to their integration into the profession.

"When interviewed during my search for the internship, an employer made it clear to me that the average age in his office was 31 years and that his company was looking for people who could make a career with his company. He felt that with my 50s, I was very old for the job. The other problem for him was that I also had no Quebec experience. I was therefore refused the post" (Participant 1).

After analyzing the verbatim, and based on our results, we find that the age, race (physical appearance of the immigrant through the photos or his appearance), the cultural factor (the accent of the accountant trained in abroad), the average obtained can be considered as barriers to the professional integration of foreign accountants within the profession. These criteria have been grouped into the discriminatory and subjective factors used by employers.

\subsection{Language Barriers}

It should be noted that several of these participants are french-speaking, and they were sometimes confronted with the bilingual factor which came up several times during the job interviews.

However, some respondents said that they had all been able to get a job or an internship despite the fact that they spoke little English. But, they say they would have had more chances and choices if they had been perfectly bilingual.

\section{Conclusion}

The purpose of our study was to highlight and understand the barriers to the integration of internationally trained accountants into the profession when they immigrate to another country. In our case, we focused on the Quebec CPA Order. According to the Office des Professions du Québec, despite the growing number of immigrants who decide to settle in Quebec, and the shortage of labor, 
many internationally trained professionals experience difficulties integrating into their professional field. The literature on professionalization and more particularly on professional integration is vast (e.g., Annisette, 2017; Annisette \& Trivedi, 2013; Boudarbat \& Boulet, 2010; Carnegie \& Edwards, 2001; Jacobs, 2003; Poullaos, 2016; Roger \& Orthodoxia, 2011). The issue of barriers to professional integration has been addressed, but the results vary from one context to another. Very few studies have looked at the case of Quebec.

The main conclusions of our study show that the barriers to the integration of immigrant accountants are present at three levels: before and directly after arriving in Quebec, during the university course, and finally when looking for the compulsory internship (24 months). At the first level, there are information barriers, barriers related to people from the same cultural community as the immigrant, and barriers related to family and social factors and barriers related to the financial factor.

At the second level, there are procedural barriers, which are related to the size of the economy of the country of origin. At the third level, these are barriers linked to technical skills, social network, discriminatory factors (marks obtained, age, physical appearance, cultural factor through accent, lack of experience professional Quebec), and finally, language barriers. We also come to the conclusion that there are factors that we describe as natural: these are family and social factors (the number of children or dependents of the immigrant and his marital status), the influence of people of the same ethnicity as the immigrant (the quality of the information he receives from these people). In addition, the immigrant person's state of mind upon arrival in Quebec (having clear goals about their professional orientation before immigrating, their level of self-confidence, and their determination) may be barriers to their integration into the CPA accounting profession. From these results, we group all of these factors into two main groups: the barrier factors under the immigrant's control and the factors beyond his control. In light of Weber's $(1971,1975)$ theory of social closure, the work of Murphy $(1984,1988)$ and the literature on our subject, we have come to the conclusion that, despite the efforts of State and order to be as fair as possible towards immigrants and to facilitate their integration, there are factors of collectivist barriers such as race, ethnicity, language, class, social network of the immigrant, who persist as barriers to the integration of internationally trained professionals. It is very true that the province of Quebec puts forward competence, professional experience and academic excellence which, according to Weber (1971, 1975), are considered to be factors of individualists. But in our study, collectivist factors have a big influence.

Our research is consistent with the work of Weber $(1971,1975)$. It shows that closure codes still exist in social relations despite all the opening efforts of the federal and provincial governments of Canada. On a practical level, our work could serve as a guide for immigrants and more particularly for immigrant accountants who arrive and want to join the CPA Order. Our work could also 
serve as a guide for the CPA Order, community and government organizations responsible for immigration and the integration of newcomers, to better guide and assist immigrants in their integration.

\section{Limitations and Future Research Avenues}

Like any research work, ours has limits and in the light of these, we make proposals for future research avenues.

The first limit is the fact that several participants are UQAM students may make the respondent not feel free to talk about the barrier factors linked to the university or the education system.

Future research could focus on people who are at a university other than UQAM. Another line of research could be interested in what happens to immigrant accountants who fail to integrate into the profession. Another study could also be just interested in immigrant accountants who already have the CPA designation and who are active on the job market to analyze the quality of life of these people compared to natives of Quebec who have the same qualification. Integration should also be analyzed over the immigrant's entire working life (from his arrival in Quebec until retirement age).

The second limit of our work is the impossible generalization of results, due to the size of the sample and because of the fact that we were only interested in the province of Quebec. Our results may be different in other Canadian provinces. A future study could be carried out in other provinces of Canada to compare it with the Province of Quebec.

The third limit is related to the fact that our sample includes just people who are in the process of being CPA or who have completed their path means that all the barrier factors may not have been identified. Indeed, it would be interesting to question the accounting professionals who arrived in Quebec, who are not at all in the process of integrating the accounting profession and who have downright made a career change.

\section{Conflicts of Interest}

The authors declare no conflicts of interest regarding the publication of this paper.

\section{References}

Annisette, M. (2000). Imperialism and the Professions: The Education and Certification of Accountants in Trinidad and Tobago. Accounting, Organizations and Society, 25, 631-659. https://doi.org/10.1016/S0361-3682(99)00061-6

Annisette, M. (2003). The Colour of Accountancy: Examining the Salience of Race in a Professionalization Project. Accounting, Organizations and Society, 28, 639-674. https://doi.org/10.1016/S0361-3682(02)00030-2

Annisette, M. (2017). Discourse of the Professions: The Making, Normalizing and Taming of Ontario's “Foreign-Trained Accountant". Accounting, Organizations and Society, 60, 37-61. https://doi.org/10.1016/j.aos.2017.06.006 
Annisette, M., \& Trivedi, V.U. (2013). Globalization, Paradox and the (Un)Making of Identities: Immigrant Chartered Accountants of India in Canada. Accounting, Organizations and Society, 38, 1-29. https://doi.org/10.1016/j.aos.2012.08.004

Annisette, M., \& Prasard, A. (2017). Critical Accounting Research in Hyper-Racial Times. Critical Perspectives on Accounting, 43, 5-19. https://doi.org/10.1016/j.cpa.2016.06.002

Baluta, I. (2011). Fermeture Sociale, Différence et Diversité: Des Enjeux Identitaires. Journal of Comparative Research in Anthropology and Sociology, 2, 1-10.

Bédard, J.-L., Papi, C., Beauchamp-Goyette, F., \& Dieng, M. (2018). Admission aux Professions Réglementées: Immigration, Gouvernance du Système Professionnel et Disjonctions Institutionnelles. Analyse Comparative, Identification de Bonnes Pratiques et Recommandations Pour les Professions Réglementées au Canada. Ottawa: Conseil de Recherches en Sciences Humaines du Canada.

Boudarbat, B., \& Boulet, M. (2010, 2010). Immigration au Québec: Politiques et Intégration au Marché du Travail. Montréal: Centre Interuniversitaire de Recherche en Analyse des Organisations.

Caramanis, C. (2002). The Interplay between Professional Groups, the State and Supranational Agents: Pax Americana in the Age of 'Globalisation'. Accounting, Organizations and Society, 27, 379-408. https://doi.org/10.1016/S0361-3682(01)00006-X

Carnegie, G. D., \& Edwards, J. R. (2001). The Construction of the Professional Accountant: The Case of the Incorporated Institute of Accountants, Victoria (1886). Accounting, Organizations and Society, 26, 301-325. https://doi.org/10.1016/S0361-3682(00)00039-8

Chua, W. F., \& Poullaos, C. (1998). The Dynamics of "Closure" Amidst the Construction of Market, Profession, Empire and Nationhood: An Historical Analysis of an Australian Accounting Association, 1886-1903. Accounting, Organizations and Society, 23, 155-187. https://doi.org/10.1016/S0361-3682(97)00009-3

Chua, W. F., \& Poullaos, C. (2002). The Empire Strikes Back? An Exploration of Centre-Periphery Interaction between the ICAEW and Accounting Associations in the Self-Governing Colonies of Australia, Canada and South Africa, 1880-1907. Accounting, Organizations and Society, 27, 409-445.

https://doi.org/10.1016/S0361-3682(01)00020-4

Collins, R. (1979). The Credential Society. New York, NY: Academic Press.

Dietrich, A., \& Moysan-Louazel, A. (2012). Conflits de Territoire dans la Profession d'Expert-Comptable. [Conflicts of Territory in the Accountancy Profession]. Revue Française de Socio-Économie, 9, 227-245. https://doi.org/10.3917/rfse.009.0227

Dyball, M. C., Poullaos, C., \& Chua, W. F. (2007). Accounting and Empire: Professionalization as Resistance: The Case of Philippines. Critical Perspectives on Accounting, 18, 415-449. https://doi.org/10.1016/j.cpa.2006.01.008

Gall, M., Gall, J., \& Borg, W. (2007). Educational Research: An Introduction (8th ed). Boston, MA: Pearson/Allyn \& Bacon.

Gobe, E. (2011). Lawyers, the Old Regime, and the Revolution. Profession and Public Commitment in Tunisia in the 2000s. Politique Africaine, 122, 179-197. https://doi.org/10.3917/polaf.122.0179

Gomes, D., Carnegie, G. D. and Rodrigues, L. L. (2013). Accounting as a Technology of Government in the Portuguese Empire: The Development, Application and Enforcement of Accounting Rules during the Pombaline Era (1761-1777). European Accounting Review, 23, 87-115. https://doi.org/10.1080/09638180.2013.788981 
Guozhen, H., Fowler, C. J., \& Baskerville, R. F. (2016). Entering the Accounting Profession: The Operationalization of Ethnicity-Based Discrimination. Accounting, Auditing \& Accountability Journal, 29, 1342-1366. https://doi.org/10.1108/AAAJ-07-2015-2153

Hammond, T., Clayton, B. M., \& Arnold, P. J. (2009). South Africa's Transition from Apartheid: The Role of Professional Closure in the Experiences of Black Chartered Accountants. Accounting, Organizations and Society, 34, 705-721.

https://doi.org/10.1016/j.aos.2008.09.002

Jacobs, K. (2003). Class Reproduction in Professional Recruitment: Examining the Accounting Profession. Critical Perspectives on Accounting, 14, 569-596. https://doi.org/10.1016/S1045-2354(02)00140-5

Murphy, R. (1984). The Structure of Closure: A Critique and Development of the Theories of Weber, Collins, and Parkin. British Journal of Sociology, 35, 547-567. https://doi.org/10.2307/590434

Murphy, R. (1988). Social Closure: The Theory of Monopolization and Exclusion. New York, NY: Oxford University Press.

Paradeise, C. (2008). Autonomie et Régulation: Retour sur Deux Notions-Clés. In Action Publique et Légitimité Professionnelle (pp. 194-200). Paris: Librairie Générale de Droit et de Jurisprudence.

Parkin, F. (1979). The Marxist Theory of Class: A Bourgeois Critique. London: Tavistock.

Poullaos, C. (2009). Professionalisation. In J. R. Edwards, \& Walker, S. P. (Eds.), The Routledge Companion to Accounting History (pp. 247-273). London: Routledge.

Poullaos, C. (2016). Canada vs Britain in the Imperial Accountancy Arena, 1908-1912: Symbolic Capital, Symbolic Violence. Accounting, Organizations and Society, 51, 47-63. https://doi.org/10.1016/j.aos.2016.05.001

Ramirez, C. (2001). Understanding Social Closure in Its Cultural Context: Accounting Practitioners in France (1920-1939). Accounting Organizations and Society, 26, 391-418. https://doi.org/10.1016/S0361-3682(00)00023-4

Roger, J., \& Orthodoxia, K. (2011). Exploring Inclusion, Exclusion and Ethnicities in the Institutional Structures of UK Accountancy. Equality, Diversity and Inclusion, 30, 482-497. https://doi.org/10.1108/02610151111157701

Uche, C. (2002). Professional Accounting Development in Nigeria: Threats from the Inside and Outside. Accounting, Organizations and Society, 27, 471-496. https://doi.org/10.1016/S0361-3682(01)00007-1

Walker, S. P. (1988). The Society of Accountants in Edinburgh: 1854-1914: A Study of Recruitment to a New Profession. London: Routledge.

Weber, M. (1971). Économie et Société. Paris: Plon.

Weber, M. (1975). Économie et Société: Les Catégories de la Sociologie. París: Plon.

Willmott, H. (1986). Organising the Profession: A Theoretical and Historical Examination of the Development of the Major Accountancy Bodies in the U.K. Accounting, Organizations and Society, 11, 555-580. https://doi.org/10.1016/0361-3682(86)90036-X

Yin, R. K. (2014). Case Study Research Design and Methods (5th ed). Thousand Oaks, CA: Sage Publications, Inc. 